\title{
Excavating the Past: Rememories and Healing in Toni Morrison's Beloved
}

\author{
Rosilene Cássia Freitas de Aquino
}

\begin{abstract}
This essay discusses the possibility of the combination of the social with the aesthetic functions of African American literature. It analyses how the main characters of Morrison's Beloved are portrayed not just as individual and fictional types, but also as collective and historical ones, through which African American historical memory and culture are revealed in slavery time.
\end{abstract}

Key words: African American history. Rememories. Healing. Slavery.

The dedication of Toni Morrison's Beloved -"Sixty Million and more"- reveals Toni Morrison's concern with African American history. Her novel is dedicated to Africans and African American slaves who suffered and were murdered throughout the historical period of The Middle Passage and Slavery. Beloved exemplifies Morrison's view of the possibility of combination of the social with the aesthetic functions of African American literature: it has to be beautiful and "unquestionably political" (Walder 332). Morrison's narrative bears witness of the historical past of slavery in the United States. In Beloved, which I see as a living chronicle of slavery, Morrison's characters, specifically the character called Beloved, can be seen not just as individual and fictional types, but also as collective and historical ones, which represent their ancestors and community in the slavery time. Through Beloved's presence and actions within the narrative, and also by the use of an outstanding imagery, metaphors, supernatural elements, oral tradition, and the African American views of time and reality, Morrison remembers and unveils a past that still remains partially obscure, distorted, and inaccessible to the American society, specially to African Americans who had been denied their own history.

Concerning the importance of the social and political role of literature for people of African descent, Michael Ryan emphasizes that African American writers, among them Toni Morrison, are naturally engaged in cultural and political issues, such as "inter-ethnic relations, racial identity, homeland, exile, Diaspora, nationhood" (147), among others. According to Ryan's view, it is relevant to mention that, in Morrison's Beloved, African American cultural and political issues can be distinguished in the way her characters are portrayed in order to reveal not only their personal and collective 
struggle to overcome all racist mistreatments they faced during slavery times, but also the struggle of all African Americans, until the present time. Ryan reveals that:

To read Morrison's Beloved is necessarily to ask what it means to be black and African descended in a largely white America [...] It is to ask how the long story of mistreatment of one social group by another weighs upon the present. And it is to confront the ghosts of one's culture, the ghost of the overseer, and the ghost of the slave as well as to remember what shouldn't be forgotten. (148)

These ghosts pointed out by Ryan in Morrison's Beloved are remarkably present in African American political, cultural, and social lives, until the present. Morrison wakes up those ghosts that have been haunting American society for so long. In the novel, the ghost of Sethe's daughter is a metaphor for all those slaves who suffered with the atrocities of slavery. This novel opens important questionings concerning the way African American culture, traditions, and history have been misunderstood, distorted, and erased from a white official history and discourse. Beloved goes beyond a white historiographical perspective and shows a different point of view. It negotiates a re-reading of American history, that is, it can instigate a conscious reflection and, as Ryan (148) puts it, a possible "reconsideration of the history of white discourse from an interracial perspective". Through a conscious reading of Beloved some chapters of American History, for instance Slavery, can be discussed and reevaluated not only through white eyes, but also through African Americans' own eyes.

Morrison's narrative structure in Beloved illustrates how she portrays the character Beloved in order to represent those thousands of slaves who were forgotten and had their (hi)stories neglected and erased from people's minds. Morrison's narrative voice points out:

Everybody knew what she was called, but nobody anywhere knew her name [...] Although she has claim, she was not claimed [...] They forgot her like a bad dream [...] Remembering seemed unwise [...] They can touch it if they like, but they don't, because they know things will never be the same if they do. (274-75)

Such poetic words reveal a claim for justice that is ignored because of the consequences that it can provoke. The way Morrison depicts Beloved's presence throughout the novel as being "sad", "grief", "lonely" and "rebuked" (8, 9, 13), and also the way Beloved's actions showed how she craved Sethe's love and presence emphasize Beloved's connection with the other dead slaves who had their stories abruptly interrupted and were deprived of the love of their mothers and families.

Through the personal (hi)stories of her characters, Morrison reveals how slaves were deprived of their mates, children, and family connections. For instance, Morrison's narrative voice gives the testimony of how Baby Suggs's family as well as other people she knew "had been hanged, rented out, loaned out, bought up, brought back, stored up, mortgaged, won, stolen or seized" (23). The novel exposes physical and psychological scars, lynching, murdering, and the humiliation of millions of people who were seen as objects of exchange.

Morrison's processes of remembering and re-membering the African American past represent a possibility of redemption and healing of physical and psychological wounds. ${ }^{1}$ Morrison's main characters have to rememorize and face their past in order to get maturity, release their personal and collective traumas, and transform their own present.

Morrison remembers and re-presents slavery and its traumas as a very personal and real experience. ${ }^{2}$ Morrison's novel, which combines facts and fiction, has an extraordinary sense of place, history, and community. Her novel presents dates, places 
and names that bear witness of that historical time. Morrison's creative narrative transports the readers to Sweet Home, in Kentucky, and to 124 Bluestone Road, in Cincinnati, during slavery, before and after The Civil War. For example, Beloved - the baby ghost and later the flesh-and-blood apparition of Sethe's murdered daughter embodies the collective memory of those who suffered slavery. She connects the world of the dead with the world of the living, and also personifies all motherless and fatherless slaves who were prevented from be(ing)loved. She also brings to the surface a deep reflection about love and the traumas caused by the fact that slaves were not allowed to have connections, friendship, and family. Their families were dismembered and they were disconnected from their (hi)stories.

Beloved is an essential figure constructed by Morrison in order to bring to the surface all (hi)stories that have been interrupted or forgotten. She is a testimony of personal and collective slave stories that have survived mortality, being repeated over and over in order not to be forgotten, but remembered in a way of bearing witness about the brutality of Slavery era. Through Beloved's presence, Morrison's characters are constrained to remember and share their past experiences, traumas, and (hi)stories in a way that brings healing and transformation to their lives. In a similar way, through the reading of her works, American society, especially African Americans, may confront, remember, and re-examine their historical past of slavery in order to get individual and collective healing through the collective sharing of information.

In an interview to Gail Caldwell, Morrison points out that "the past, until you confront it, until you live through it, it keeps coming back in other forms. The shapes redesign themselves in other constellations, until you get a chance to play it over again" (Taylor-Guthrie 241). Morrison's Beloved is a way of playing it over: by remembering the past, confronting it, and bringing transformation to the present. According to Roland Walter (243), "the narrativization of deliberately forgotten traumatic events creates a space for possible healing as it provides a consensual reality and collective memory through which fragments of personal memory can be assembled, reconstructed and displayed with a tacit assumption of validity". Sethe, the protagonist of the novel, has to rememorize and narrate her painful traumas in order to transform and reconstruct her dismembered and fragile present. Just after retelling her harmful experiences from slavery she is able to release herself from such psychological wounds. Then she may instigate a healing process, not only for her, but also for her community that needed to accept her again.

As Morrison's narrative shows, it is necessary to recover these traumatic, forgotten, and mutilated (hi)stories in order to re-member and rearticulate the pieces of African Americans'history which still remain maimed. Therefore, the act of remembering the African Americans' past is also intimately connected to the act of rememorizing their individual and collective past. After putting the parts of their collective (hi)story together, African Americans are able to re-member and rearticulate their own personal (hi)stories.

In these processes of re-membering and retelling the African Americans' experience of slavery, Beloved is crucial to establish a connection between natural and supernatural, past and present, and also between the world of the living and the world of the ancestors. She represents the living memory of African American ancestors, and her presence functions as a healing force that compels the other characters to retell their stories. Through their remembrances or "rememories" (Morrison 36) from the past, they can reshape and re-signify their fragmented identities, and reach a possibility of redemption and healing of their physical and psychological wounds. 
Beloved's return wakes up all Sethe's losses: the loss of her family, of her community life, and especially of her self-love. By trying to bury her past, Sethe loses the connection with her ancestors and with her collective identity. She feels exiled and homeless in her own house and neighborhood.

Therefore, Beloved represents a possibility of a reawakening of past experiences, and, through her voice, Morrison also creates an aesthetical and political engagement with the African American historical past. Beloved's fragmented discourse is a powerful testimony of the past, which reflects not only her individual experience, but also recreates a connection with the world of her ancestors, which is represented by the suffering of slaves during The Middle Passage. Those aspects of her fragmented and disconnected discourse are also shown in the form of the text, with its blank spaces and disconnected sentences:

"someone is trembling I can feel it over here he is fighting hard to leave his body which is a small bird trembling there is no room to tremble so he is not able to die The iron circle is around our neck I would bite the circle around her neck I know she does not like it" (211). ${ }^{3}$

She represents all those unnamed, de-bodied and unvoiced slaves who died during The Middle Passage. In fragmented passages of the novel, the use of the personal pronoun "we" reinforces Beloved's voice as a representation of the collective voice and memory of murdered slaves who were thrown into the water: "they are not crouching now we are they are floating on the water" (212).

Concerning Beloved's role as an instrument of healing for her mother, it can be noticed, throughout the novel, how she induces Sethe to talk about her traumatic experiences from the past. Thus, the readers become aware of Sethe's childhood as a slave, the lynching of her mother, the sufferings in Sweet Home and her escape from there, the dismembering of her family, among other painful remembrances. Her rememories are painful and hurt her, but they are, at the same time, necessary to her process of healing. Sethe's past haunts her, but she becomes aware that it is impossible just to continue hiding, forgetting, or even avoiding it, because it is somehow "waiting for" (35) her. Later she is able to understand that her past is connected with her present as she says: "Some things go. Pass on. Some things just stay. Some things you forget. Other things you never do ... Places, places are still there ... Nothing ever dies ... it is still there, waiting for you" (36). After recognizing the remarkable connection between her past and her frail present, Sethe involuntarily initiates a series of actions of healing and her fragmented rememory seems to unconsciously enable her to transform and restore her present by questioning herself about what was valuable or not. By rememorizing her past, Sethe realized how slavery did not allow her to have her mother's presence, and she found out how she still lacked her mother's love and companionship. She also remembered how she was scared of not recognizing her own mother, because they were not allowed to talk to each other or even to see each other.

Through Sethe's process of retelling her past stories, her displaced and fragmented identity and self could be re-membered and re-signified. She also may be able to reconnect herself with her collective identity that also needed to be restored. By bringing to the surface her traumas, she could rehabilitate herself and restart where the thread was cut - individually and collectively - that is, where the damage occurred. Her isolation from her community and her dislocated self were revealed in her fragmented and gapped narrative from her rememories of her traumatic past. In a turbulent way, she remembers her most hurtful experiences from the past: her 
mother's and her daughter's death. Sethe's disjointed voice, full of gaps and ruptures, reveals how unpleasant it is both to speak about the unspeakable and to remember a past that cannot be spoken: "Beloved, she my daughter, She mine [...] my love was tough and she back now [...] I never saw her own smile [...] I wonder what they was doing when they was caught [...] before they hanged her and let me be one [...]" (20103). Her rememories about that horrendous past were so agonizing that they came in broken and disconnected parts in which the death of her mother was fused with of her daughter's.

Indeed, Sethe's real healing initiates with her reintegration into her community, at the end of the novel, because being part of a community again means that she was not alone anymore, as she felt after her mother's and daughter's deaths. The community ritual of rescuing her is a symbol of forgiveness. Sethe's complete healing seems to occur because of an important process of the reconstruction and the acceptance of her self-love, as Paul D once affirmed to her: "You your best thing, Sethe. You are" (273). Sethe has to learn how to love herself, and accept herself as a person who needs to give and take love, as her mother-in-law, Baby Suggs, had taught her and the other former slaves at the Clearing: "we flesh; flesh that weeps, laughs; flesh that dances on bare feet in grass. Love it. Love it hard [...] Love your eyes ... your hands ... your face ... You got to love it, You!" (88).

Therefore, in Beloved, the presence of the past is decisive to the transformation of the present of most of the characters, especially Sethe's present. In this novel, as I have emphasized before, the past returns in the form of Sethe's dead daughter Beloved, who comes back from the "other side" (75) eager to join the broken parts of her history. She claims for her place and for the history to which she thinks she belongs. She reclaims her place in Sethe's history and present life as she emphatically says to her sister Denver: "She (Sethe) is the one I need [...] I belong here [...] this is where I am" (76). Therefore, Beloved represents the personal, social, and spiritual unease that involves the era of slavery, in which thousands of slaves were victims of those unspeakable times.

As the narrative suggests, Beloved's presence symbolizes the past that haunts the present by not being fairly told and analyzed throughout the centuries. It has to be remembered, re-membered, and re-examined in order to be accommodated, otherwise it will continue as fragmented and disconnected rememories that cannot be controlled or forgotten. Thus, in Morrison's narrative, African Americans' collective rememories are made alive in Beloved's broken and disconnected speech. By trying to forget and bury a painful past still alive, Americans are forced to face the ghosts that will always come to reclaim their (hi)stories and also to remind American society that there is a past to be re-examined and restored in order to bring justice and healing of unspeakable wounds.

Therefore, Morrison's narrative that reappropriates, remembers, and re-members the African American past is an attempt to pass on that chapter of American history. A past that remains unspeakable, although it urges for discussion and revision, in spite of the fact that the processes of remembering and re-membering are not painless. As Amy - a white girl who helped Sethe to deliver Denver - says: "more it hurt more better it is. Can't nothing heal without pain" (78). Beloved's voice, presence and actions show that she returns to bring pain, but at the same time, healing, and, above all, make people remember what cannot be forgotten. Definitively, as Morrison seems to state, the slavery history is a story to pass on. 
Notas

${ }_{1}$ The articulate and to put the parts together.

2 The term "re-present" is used here in the sense proposed by the author who brings to the present times, social, political, and historical issues related to slavery in order to re-examine and reflect on them.

${ }^{3}$ The text has those blank spaces that may be seen as Beloved's fragmented self, as a result of her personal losses, lack of love, and absence of personal and collective history.

\section{Resumo}

Este ensaio discute a possibilidade de combinação das funções social e estética da literatura afro-americana. Ele analisa como os personagens principais do romance Beloved são representados não apenas como tipos individuais e fictícios, mas também como personagens coletivos e históricos, pelos quais a memória histórica e a cultura dos afro-americanos são reveladas nos tempos da escravidão.

Palavras-chave: História afro-americana. Rememórias. Cura. Escravidão.

\section{Works Cited}

Morrison, Toni. Beloved. New York: Plume, 1988.

Ryan, Michael. Literary Theory: A Practical Introduction. Oxford: Blackwell, 1999.

Taylor-Guthrie, Danille, ed. Conversations with Toni Morrison. Jackson: UP of Mississippi, 1994.

Walder, Dennis, ed. Literature in the Modern World: Critical Essays and Documents. Oxford: Oxford UP, 1990. 326-32.

Walter, Roland. Narrative Identities: (Inter) Cultural In-Betweeness in the Americas. New York: Peter Lang, 2003. 